\title{
STUDY OF VARIOUS DETERMINANTS AND ITS INFLUENCE ON FINANCIAL LITERACY: AN EMPIRICAL STUDY IN THE CITY OF AHMEDABAD
}

\author{
Mr Tarun Bhagat, Dr. Sagar Dave \\ Research Scholar \\ SD School of Commerce \\ Gujarat University \\ Ahmedabad \\ Principal \\ Government Arts College \\ Megharaj \\ Gujarat
}

\begin{abstract}
Financial Literacy has become a priority area across the world in recent years. In a complex and globalized marketplace, a myriad of products is offered in the financial market, and the accessibility of products has also increased. This has made it imperative for individuals to be well equipped with the necessary financial knowledge and awareness to use their financial resources in an optimum way. The study examines the financial literacy of the people by using a questionnaire developed by self-validated scales of determinants of financial literacy. The major findings of the data interpretation and analysis reveals that there are major six determinants that has very strong influence on level of financial literacy. The present study offers the first ever comprehensive insight into the financial literacy of the Ahmedabad region
\end{abstract}

Keywords: Financial Attitude, Financial Behaviour, Financial Knowledge, Financial Literacy, Financial Planning.

\section{INTRODUCTION}

In today's financial world, the importance of financial education is recognized globally as a key factor in the financial well-being of individuals and the financial stability of the country, and today consumers are entering the risky markets they face. Various financial products and services. The embarrassing choice of these products and clever advertising often deceive consumers and prevent them from understanding the fine print of complex information and the downside risks associated with it. Technological innovations make things even more complicated. It has led to the explosion of new products, which increases the household's responsibility and risk in making financial decisions. Financial consumers need to have basic financial knowledge and skills to help them navigate and select a complex range of products and services.

It best suits their needs and resources. The complexity, exposure to advanced financial technologies such as mobile and online payments, increased personal financial responsibility due to the transition from a defined pension plan to a contribution plan, and concerns over retirement plans and health care needs make it essential to understand financial concepts. is. Make smart decisions about financial transactions. financial literacy improves household knowledge and builds trust to help you manage financial problems towards a safe financial future.

We know inflation well and risk diversification tends to make more plans for retirement (Lusardi \& Mitchell, 2009; Hastings \& Mitchell, 2011; Lusardi \& Mitchell, 2011). The findings of a study by Klapper and Panos (2011) show that financial information is well-suited and is linked to retirement planning. The resulting financial awareness and ethical behavior leads to adverse financial consequences that have a negative impact on a person's financial well-being. Lack of knowledge of key economic concepts and skills causes people to fall into lower financial decisions (Hastings \& Mitchell, 2011). People with little financial experience hold negative views on financial concepts, and, as a result, make poor financial decisions (Chen \& Volpe, 1998) They participate less in the stock market (Rooij, Lusardi, \& Alessie, 2007), have better credit practices, accumulate less wealth without good retirement plans (Lusardi, 2008; Lusardi \& Mitchell, 2008; 2009); and they are more likely to enter into more expensive transactions (Lucardi \& Tufano, 2009) in terms of financial literacy partners. The protection of financial consumers also requires financial knowledge as it makes people aware of the risks involved in financial products and manages their high interest rates. 


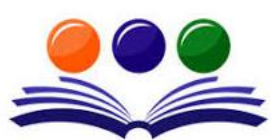

GRAND ACADEMIC PORTAL RESEARCH JOURNALS

A GLOBAL JOURNAL OF SOCIAL SCIENCES

( ISSN - 2581-5830 )

Impact Factor - SJIF - 4.998, IIFS - 4.375

Globally peer-reviewed and open access journal.

LITERATURE REVIEW

Kamal Gupta et al. (2014), assessed financial literacy of 87 Kangra County Micro-entrepreneurs of Himalaya Pradesh based on record keeping, different institutional perceptions, savings, investment plans, Savings management and various loan products. on bank loans, little awareness of other financial institutions. Overall low financial skills, reflected in poor recordkeeping, poor cash management, improper savings habits, and less awareness of financial products.

Bahadur (2015), analyzed two pillars of the economy: financial understanding and financial inclusion and its current perspectives as well as people's perspectives about financial instruments. It is found that the level of financial literacy was very low and recommended a financial incentive. Fluency at school level, national programs and effort through the grassroots level.

K N Narendra (2014 ), discussed the role of a Financial Planner in the age of information overload. to educate and launch revolution in India.

Sumit Agarwal et al. (2010), we surveyed 1,694 Hyderabad respondents interested in personal finance on their investment behavior, liability choices, risk tolerance and insurance usage. Data for analysis provided by Investment Yogi Financial Advisory Services.

Ratna Achuta Paluri (2016) analyzed the factors that influence the economic attitude of Indian women and categorized Indian women based on their attitude. Nine Variables: Anxiety, Interest in Financial Issues, Intuitive Decisions, Preventive Savings, Free Spending, Material and Deadly Attitudes, Trend Studies in Planning Long-Term and Short-Term Financial Goals, Women in Nasik We used confirmatory factor analysis to cluster the. Cluster analysis categorized customers into wise consumers, conservative consumers, favorable consumers, and uncertain consumers. Only one-third of the respondents did not buy financial products, and the most preferred products were time deposits and insurance. We also found that cluster 1 and cluster 3 were more attractive in that order. Marketer, Cluster 4 is not attractive.

Mathavathani etal。 (2014), focused on the financial literacy of rural women in Tamil Nadu based on three factors: knowledge, behavior and attitude (2013) conducted a survey of 516 office workers in Himachal Pradesh using multi-step sampling to check financial literacy levels. We found that the overall level of literacy was low and that men had higher levels of financial literacy than women. Education, Income, Natural Levels Employment and workplaces affect financial literacy, while geographic regions do not affect financial literacy Harsha V Jariwala (2014) considers 44 variables in India We evaluated the level of financial literacy of individual investors in Gujarat and their impact on investment decisions. The survey found that $39.2 \%$ of 285 respondents had high levels of financial literacy, and that financial literacy had a statistically significant impact on investment decisions.

Priyanka Agarwal, et al. (2015) Focuses on the importance of financial literacy in managing the financial and investment patterns of educated and uneducated female staff (20 educated and 20 uneducated female staff) in the education sector of the Jhansi district. I have put it. Recognizing Investment Avenue, we invest our savings in time deposits at banks and post offices.

\section{RESEARCH OBJECTIVES}

1. To identify major determinants of the Financial Literacy

2. To evaluate impact of the various determinants on level of financial literacy

3. To Study nature and intensity of the relationship between Financial Literacy and other independent determinants.

\section{Research Hypothesis}

H0: There is no significant influence of all the determinants on level of financial literacy

H1: There is significant influence of all the determinants on level of financial literacy.

\section{RESEARCH METHODOLOGY}

Research Design: Descriptive and Causal Design

Contact Method: Personal Interview survey

Sample Size: 520

Sampling Method: Non Probability convenience sampling

Research Instrument: 5 Point Liker Scale Questionnaire 


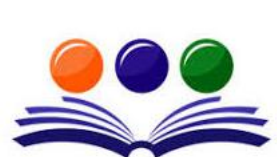

GRAND ACADEMIC PORTAL RESEARCH JOURNALS
GAP GYAN

A GLOBAL JOURNAL OF SOCIAL SCIENCES

( ISSN - 2581-5830 )

Impact Factor - SJIF - 4.998, IIFS - 4.375

Globally peer-reviewed and open access journal.

\section{DATA ANALYSIS AND INTERPRETATION}

In the next part of the study carry forward same hypothesis using multiple regression. All six factors are inserted as independent variables combined and Financial Literacy inserted as the dependent variable. Mean score was taken as the representative value for that particular variable.

Person correlation was performed first to make base for the multiple regression. Table provides the Coefficient of relation between all independent variables and dependent variable.

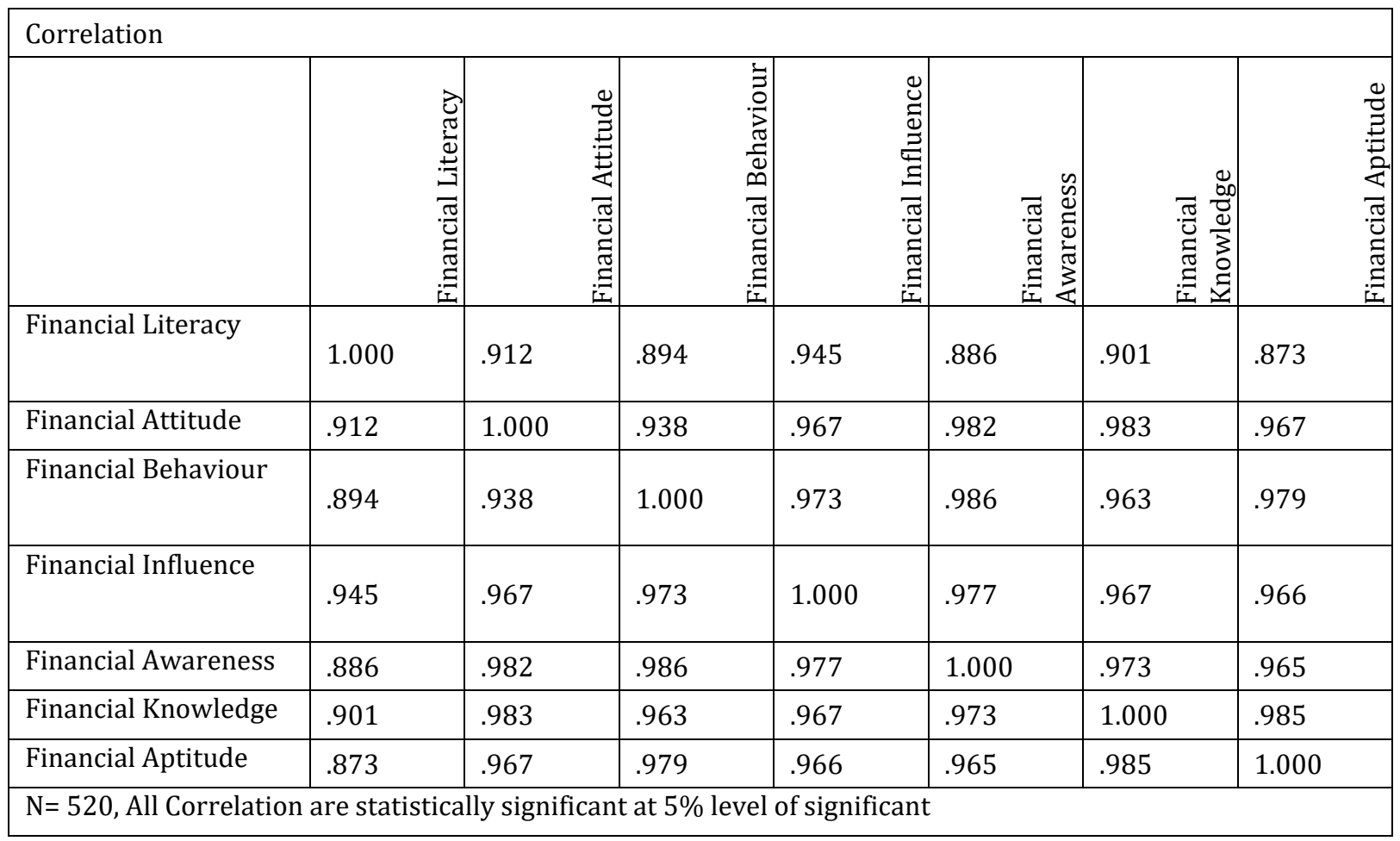

Coefficient of correlation was positive for all the variables and varied between 0.963 to 0.986 . All coefficient of correlation were statistically significant at $5 \%$ level of the significant. Correlation summary provides the good base for the multiple regression.

The model summary of Financial Literacy and all six explored variables is given in Table and it shows the coefficient of determination $\left(\mathrm{R}^{2}\right)$ under model which is 0.977 , which meant all six factors combine explained 97.7 percent of the variations in Financial Literacy.

\begin{tabular}{|c|c|c|c|c|c|c|c|c|c|}
\hline \multicolumn{10}{|c|}{ Model Summaryb } \\
\hline \multirow[b]{2}{*}{ Model } & \multirow[b]{2}{*}{$\mathrm{R}$} & \multirow[b]{2}{*}{ R Square } & \multirow[b]{2}{*}{$\begin{array}{l}\text { Adjusted } \\
\text { R Square }\end{array}$} & \multirow[b]{2}{*}{$\begin{array}{l}\text { Std. Error } \\
\text { of the } \\
\text { Estimate }\end{array}$} & \multicolumn{5}{|c|}{ Change Statistics } \\
\hline & & & & & $\begin{array}{l}\text { R Square } \\
\text { Change }\end{array}$ & F Change & df1 & df2 & $\begin{array}{l}\text { Sig. F } \\
\text { Change }\end{array}$ \\
\hline 1 & $.987^{\mathrm{a}}$ & .977 & .956 & .24958 & .897 & 623.207 & 6 & 513 & .000 \\
\hline \multicolumn{10}{|c|}{$\begin{array}{l}\text { a. Predictors: (Constant), Financial Aptitude, Financial Influence, Financial Behaviour, Financial Awareness, } \\
\text { Financial Attitude, Financial Knowledge }\end{array}$} \\
\hline \multicolumn{10}{|c|}{ b. Dependent Variable: Financial Literacy } \\
\hline \multicolumn{10}{|c|}{ ANOVA $^{a}$} \\
\hline \multicolumn{2}{|l|}{ Model } & \multicolumn{2}{|c|}{ Sum of Squares } & Df & \multicolumn{2}{|c|}{ Mean Square } & $\mathrm{F}$ & & Sig. \\
\hline
\end{tabular}




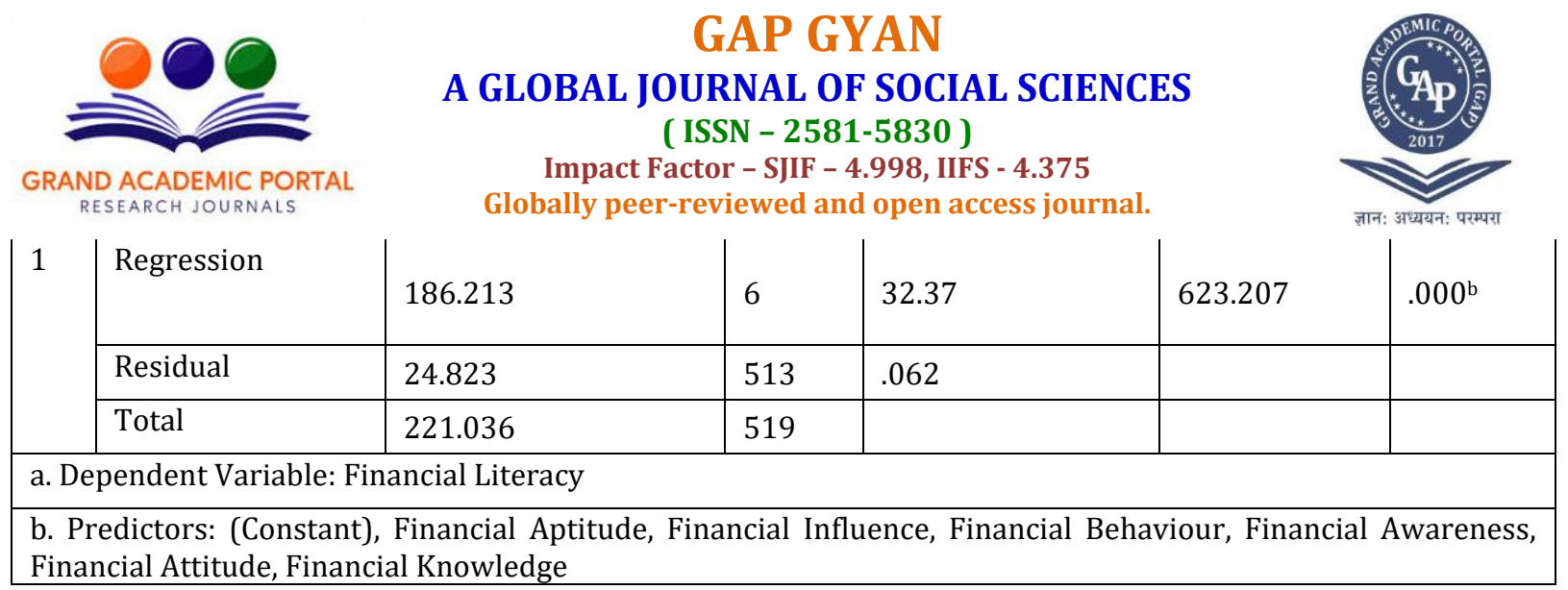

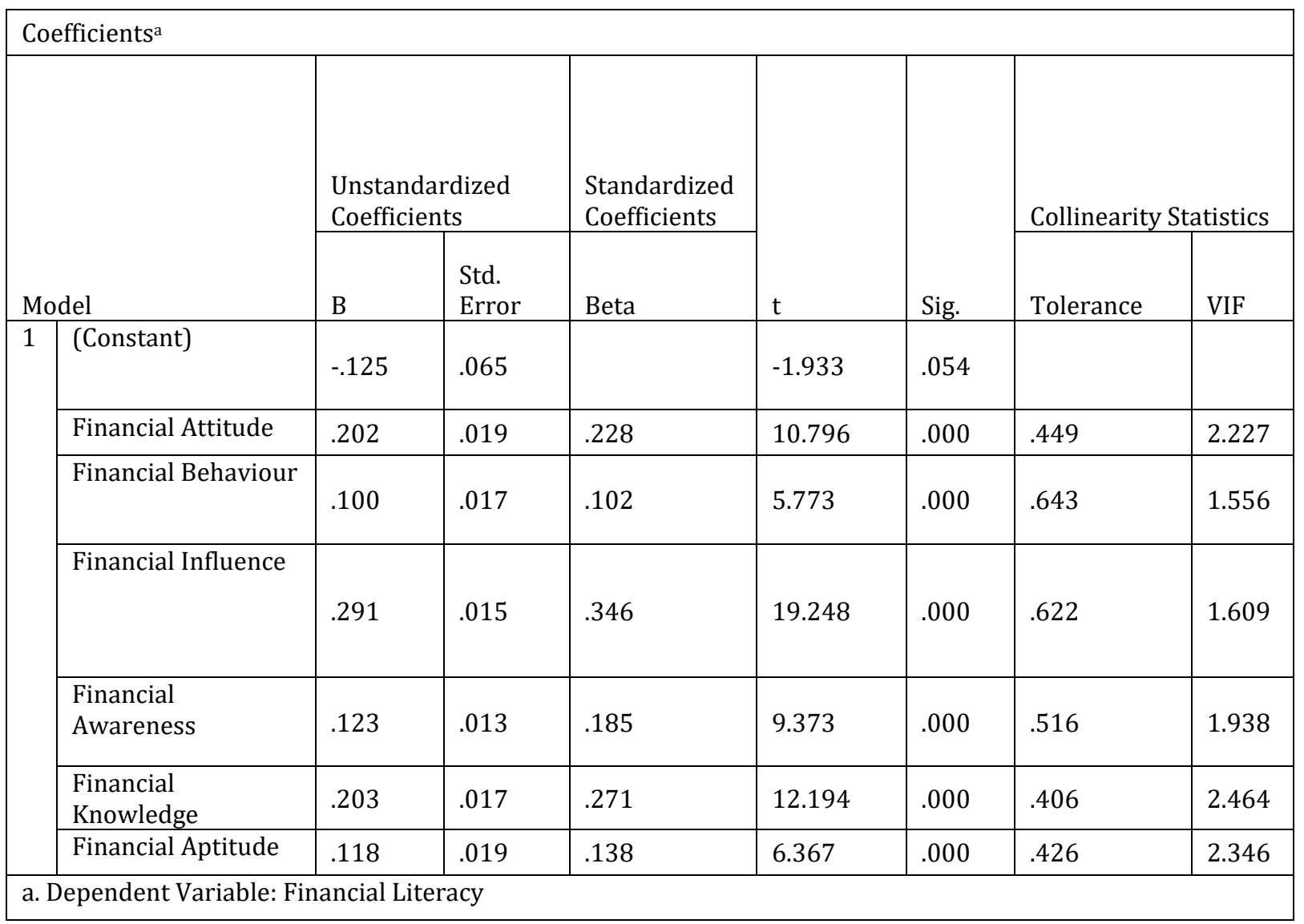

The ANOVA Table is used to assess the overall significance of the regression model. In Table, the F-value (623.207) and the $p$-value is 0.000 . This meant that model is significant as $p$-values less than 0.05 at $\alpha=0.05$ level. It further said that explored six variables significantly contribute in the variation of the Financial Literacy. Further Table provides the coefficient of the model. According to the table it can be said that all explored factors is significantly influence on the Financial Literacy.

\section{CONCLUSION}

All factors are statistically significant as the $\mathrm{p}$ value of all the factors are less than 0.05 . Among all the factors Financial Influence, Financial Knowledge and Financial Attitude are mainly contributors which influence mostly in the Financial Literacy. Other factors are also statistically significant but the intensity of the influence is low compare to other factors. Model can be written as:

Financial Literacy $=-.125+.202$ (Financial Attitude) +.100 (Financial Behaviour) +.291 (Financial Influence) + .123 (Financial Awareness) + .203 (Financial Knowledge) + .118 (Financial Aptitude)

\section{REFERENCES}

[1] Kamal Gupta and Jatinder Kaur, A study of Financial Literacy among Micro Entrepreneurs in District Kangra, IJRBM, Vol-2, Issue-2, February 2014, PP. 63-70. 


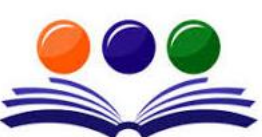

GRAND ACADEMIC PORTAL RESEARCH JOURNALS

\section{A GLOBAL JOURNAL OF SOCIAL SCIENCES}

( ISSN - 2581-5830 )

Impact Factor - SJIF - 4.998, IIFS - 4.375

Globally peer-reviewed and open access journal.

[2] Lavanya Rekha Bahadur, Financial Literacy: The Indian Story, World Journal of Social Sciences, Vol - 5, Issue-3, September 2015, PP. 45-57.

[3] K N Narendra, Financial Literacy: A revolution waiting to happen, Proceeding of COFP

[4] Convention 2014.

[5] ECD INFE (2011) Measuring Financial Literacy: Core Questionnaire in Measuring Financial Literacy: Questionnaire and Guidance Notes for conducting an Internationally Comparable Survey of Financial literacy. Paris: OECD.

[6] Sumit Agarwal, Gene Amromin, Douglas D Evan off, Financial Literacy and Financial Planning: Evidence from India, SSRN Electronic Journal • December 2010.

[7] Ratna Achuta Paluri, Saloni Mehra, Financial attitude based segmentation of women in India: an exploratory study, Vol. 34 Issue 5, January 2016, PP. 670 - 689.

[8] Puneet Bhushan, Yajulu Medury, Financial Literacy and its Determinants, International Journal of Engineering, Business and Enterprise Applications (IJEBEA), Vol. 4, Issue -2 May2013, PP. 155-160.

[9] V Mathavathani, Dr. M Velumani, A Study on Financial Literacy Among Rural Women in Tamilnadu, Indian Journal of Applied Research, Volme-4, Issue-12, December 2014, PP. 556-557.

[10] Harsha V Jariwala, Analysis of Financial Literacy Level of Retail Individual Investors of Gujarat State and Its Effect on Investment Decision, Journal of Business \& Finance Librarianship, November 2014, PP. 133-158.

[11] Priyanka Agarwal, Dr.Suman Yadav, Radhika Kureel, International Journal of Advance Research in Science and Engineering, Vol-1, Issue-1, 2015, PP. 54-61.

[12]Visa, Financial Literacy Survey, Indians among least financially literate people globally, Firstpost.com, December 2014. 